\title{
DIVERSITY OF ODONATES IN AGRICULTURAL FIELDS OF PANDHARKAWADA TALUKA, YAVATMAL DISTRICT, MAHARASHTRA, INDIA
}

\author{
Sarita T. Kawade \\ Department of Zoology, Bhalerao Science College, Saoner, Dist. Nagpur (MS).
}

Communicated : 10.07.19

Revision : $21.07 .19 \& 10.08 .19$

Accepted : 21.08.19

\begin{abstract}
:
The present survey has been carried out on Odonata of agricultural field, Pandharkawada taluka, Yavatmal district, Maharashtra because it is now clear that agricultural fields are unique ecosystem that provides several services to Odonates. So, different Odonates depend on these fields and their diversity also signs of good health of agroecosystem. But now a day agricultural land are gradually decreasing due to the rapid growth of highways, housing and factories. So, the Odonates of these fields are also under risk. This side of agricultural area is less highlighted so the main aim of this study to prepare a list of those odonates which use these fields. The study was carried out for a period of two years i.e. February 2014 to February 2016. A total of 23 species of Odonates were recorded during the period of study. Maximum of 11 species falls under family Libellulidae followed by 9 species falls under family Coenagrionidae and families Platycnemididae, Lestidae and Aeshnidae showed less species diversity and represented by only one species. Maximum species richness reported from Monsoon and post- Monsoon season.
\end{abstract}

Key words :- Agricultural field, Pandharkawada, Odonates, Diversity, Distribution.

\section{INTRODUCTION:}

\section{Odonata is}

carnivorous insects encompassing the damselflies and the dragonflies. Odonata play key roles in aquatic ecosystems, agroecosystems and forest ecosystems. Adult dragonflies and damselflies are the most easily recognizable insect taxa (Maiolini and Carolli, 2009), due to their comparatively larger size amongst the insects, bright colours and diurnal nature with interesting behavioural patterns. Predator odonates are very important biodiversity controlling agents. Adults are predacious, feeds on harmful insects and also on own kind while larvae are carnivorous and voracious feeders. Odonates are excellent model organisms for understanding key issues in ecology, animal behaviour, evolutionary biology and preypredator relationship because of their short life history. Globally 5,952 species of odonates are known and of this 474 species in 142 genera and 18 families exist in India (Subramanian, 2014). Maharashtra State lies in central-west India. It is one of the Odonata species rich states. Information about the odonates of Maharashtra state is documented by Prasad (1996). He studied Odonata from Maharashtra state and published in Records of Zoological Survey, where he presented a list of all the 83 species known from Maharashtra state till then, including the species recorded by Laidlaw,
$(1917,1919$ and 1920) and Fraser, (1920, 1921, 1924, 1933, 1934 and 1936). Out of the 83 species he reported, 46 species and subspecies belonging to 27 genera under 8 families examined by him, 10 species and subspecies were recorded for the first time from Maharashtra. Kulkami et.al.,(2012) reported Odonata known from Maharashtra state in Fauna of Maharashtra, and described a total of 101 species, which includes 18 species recorded after the work of Prasad, (1996).The odonata study on the broad aspect encompassing all varied agroecosystem was first done by (Rathod et al., 2012), who recorded 31 species from agroecosystem of Amravati city .The main objective of the present study was to record odonates in the agroecosystem of Pandharkawada taluka, Yavatmal district, Maharashtra. This will help to assess the present day agroecosystem health and the changes in the system of crop management in future.

\section{MATERIAL AND METHODS :-}

\section{I) Study area}

The present study has been carried out for a period of February 2014 to February 2016 and conducted in the sites from agricultural field of Pandharkawada taluka, Yavatmal district, Maharashtra, India during the four different season i.e. month of Pre-monsoon (July to September), Monsoon (October to December), Post-monsoon 
(January to March) and Summer (April to June).Odonates watching and data recording have been done once a week for each month. Pandharkawada city of Yavatmal district located at North latitude $20.0230^{\circ}$ and East latitude $78.5490^{\circ}$. Important agricultural crops in kharif season jowari, cotton, toor, tilli and soyabean whereas in Rabi season wheat and gram linseed etc. are grown. Annual normal rainfall is $1011 \mathrm{~mm}$ per year and annual temperature ranges from $8.2^{\circ}$ c to $46^{\circ} \mathrm{C}$.

\section{II) Collection and Identification of Odonates}

The survey procedure involved spotting and taking a photograph of any individual in its natural habitat, without collecting any specimens. Only doubtful species were collected using an entomological net. During the course of the survey photographic records of adult individuals of different Odonate species were maintained. The adult specimens were identified with the help of identification keys provided by Fraser (1933, 1934 and 1936); Mitra (2006); Subramanian (2005) and Andrew et al. (2009).

\section{RESULT \& DISCUSSION:}

A total of 851 individuals belonging to 23 species were recorded from agricultural field of Pandharkawada taluka, Yavatmal district, Maharashtra. The checklist of odonates, their habitat is given in Table 1. Diversity of odonates of 5 different families viz. Aeshnidae (Darners odonates), Libellulidae (Skimmers odonates), Coenagrionidae (Marsh Darts odonates), Lestidae (Spread Wings odonates) and Platycnemididae (Bush Darts odonates) were observed. Libellulidae was the most dominant family with (11species) followed by Coenagrionidae showed highest dominance with (9 species) followed by Platycnemididae, Lestidae and Aeshnidae showed less species diversity and represented by only one species. Distribution of each family is given (fig.1). Agricultural land was dominated by Aethriamanta brevipennis, which accounted for 101 individuals followed by Pseudagrion rubriceps and Copera marginipes with 97 and 78 individuals respectively. Species such as Pantala flavescens and Disparoneura qudrimacalata were recorded from soyabean crop during pre-monsoon period while Orthetrum Sabina, Brachythemis contaminata and Diplacodes trivialis were recorded from sugarcane crop during last monsoon period. Few species like Enallagma vesparum and Diplacodes haematode were not observed in first year observation but they recorded in second year observation during Premonsoon period.

\section{CONCLUSION:}

The odonata diversity and status of agroecosystem of Pandharkawada taluka, Yavatmal district is mostly high but cannot compare with past due to lack of previous data. Agro ecosystems performs a variety of ecological services to odonates beyond the production of food. So, different odonates depend on agricultural fields, but now a day due to urbanization these animals are under risk. Therefore, protection measures are necessary for these beautiful creatures. The references of odonata from the study area is very low and this study is useful for future research. The present study is first record of odonates in agricultural fields of Pandharkawada taluka.

Table 1: List of Odonata fauna in agricultural fields of Pandharkawada taluka, Yavatmal district, (Maharashtra, India) during 2014 to 2016

\begin{tabular}{|c|c|c|c|c|}
\hline $\begin{array}{l}\text { S } \\
\text { No. }\end{array}$ & $\begin{array}{l}\text { Common } \\
\text { name }\end{array}$ & Scientific name & Family & Status \\
\hline 1 & Blue Darner & $\begin{array}{l}\text { Anax } \\
\text { immaculifrons }\end{array}$ & Aeshnidae & Common \\
\hline 2 & $\begin{array}{l}\text { Scarlet } \\
\text { Marsh } \\
\text { Hawk }\end{array}$ & $\begin{array}{l}\text { Aethriamanta } \\
\text { brevipennis }\end{array}$ & Libellulidae & $\begin{array}{l}\text { Very } \\
\text { common }\end{array}$ \\
\hline 3 & Ditch Jewel & $\begin{array}{l}\text { Brachythemis } \\
\text { contaminate }\end{array}$ & Libellulidae & $\begin{array}{l}\text { Very } \\
\text { Common }\end{array}$ \\
\hline 4 & $\begin{array}{l}\text { Ruddy } \\
\text { Marsh } \\
\text { Skimmer }\end{array}$ & $\begin{array}{l}\text { Crocothemis } \\
\text { servilia }\end{array}$ & Libellulidae & Common \\
\hline 5 & $\begin{array}{l}\text { Scarlet } \\
\text { Percher }\end{array}$ & $\begin{array}{l}\text { Diplacodes } \\
\text { haematodes }\end{array}$ & Libellulidae & Rare \\
\hline 6 & $\begin{array}{l}\text { Ground } \\
\text { skimmer }\end{array}$ & $\begin{array}{l}\text { Diplocodes } \\
\text { trivialis }\end{array}$ & Libellulidae & $\begin{array}{l}\text { Very } \\
\text { common }\end{array}$ \\
\hline 7 & $\begin{array}{l}\text { Pied Paddy } \\
\text { Skimmer }\end{array}$ & $\begin{array}{l}\text { Neurothemis } \\
\text { tullia }\end{array}$ & Libellulidae & $\begin{array}{l}\text { Very } \\
\text { rare }\end{array}$ \\
\hline 8 & $\begin{array}{l}\text { Green } \\
\text { Marsh } \\
\text { Hawk }\end{array}$ & Orthetrum Sabina & Libellulidae & Common \\
\hline 9 & $\begin{array}{l}\text { Wandering } \\
\text { Glider }\end{array}$ & $\begin{array}{l}\text { Pantala } \\
\text { flavescens }\end{array}$ & Libellulidae & $\begin{array}{l}\text { Very } \\
\text { common }\end{array}$ \\
\hline 10 & $\begin{array}{l}\text { Common } \\
\text { Picture } \\
\text { Wing }\end{array}$ & $\begin{array}{l}\text { Rhyothemis } \\
\text { variegate }\end{array}$ & Libellulidae & Rare \\
\hline
\end{tabular}




\begin{tabular}{|c|c|c|c|c|}
\hline 11 & $\begin{array}{l}\text { Long } \\
\text { legged } \\
\text { Marsh } \\
\text { Glider }\end{array}$ & $\begin{array}{l}\text { Trithemis } \\
\text { pallidinervis }\end{array}$ & Libellulidae & $\begin{array}{l}\text { Very } \\
\text { common }\end{array}$ \\
\hline 12 & $\begin{array}{l}\text { Coral-tailed } \\
\text { Cloud Wing }\end{array}$ & Tholymis tillarga & Libellulidae & Rare \\
\hline 13 & $\begin{array}{l}\text { Pigmy } \\
\text { Dartlet }\end{array}$ & $\begin{array}{l}\text { Agriocnemis } \\
\text { pygmaea }\end{array}$ & Coenagrionidae & $\begin{array}{l}\text { Very } \\
\text { common }\end{array}$ \\
\hline 14 & $\begin{array}{l}\text { Coromandel } \\
\text { Marsh Dart }\end{array}$ & $\begin{array}{l}\text { Ceriagrion } \\
\text { coromandelianum }\end{array}$ & Coenagrionidae & Common \\
\hline 15 & $\begin{array}{l}\text { Azure } \\
\text { Dartlet }\end{array}$ & $\begin{array}{l}\text { Enallagma } \\
\text { parvum }\end{array}$ & Coenagrionidae & $\begin{array}{l}\text { Very } \\
\text { common }\end{array}$ \\
\hline 16 & $\begin{array}{l}\text { Vesper } \\
\text { Bluet }\end{array}$ & $\begin{array}{l}\text { Enallagma } \\
\text { vesparum }\end{array}$ & Coenagrionidae & $\begin{array}{l}\text { Very } \\
\text { rare }\end{array}$ \\
\hline 17 & $\begin{array}{l}\text { Golden } \\
\text { Darlet }\end{array}$ & Ischnura aurora & Coenagrionidae & Common \\
\hline 18 & $\begin{array}{l}\text { Brown } \\
\text { Dartlet }\end{array}$ & $\begin{array}{l}\text { Mortonagrion } \\
\text { varralli }\end{array}$ & Coenagrionidae & Common \\
\hline 19 & $\begin{array}{l}\text { Yellow- } \\
\text { striped } \\
\text { Bluedart }\end{array}$ & $\begin{array}{l}\text { Pseudagrion } \\
\text { rubriceps }\end{array}$ & Coenagrionidae & $\begin{array}{l}\text { Very } \\
\text { common }\end{array}$ \\
\hline 20 & $\begin{array}{l}\text { Brook } \\
\text { Sprite }\end{array}$ & $\begin{array}{l}\text { Pseudagrion } \\
\text { spencei }\end{array}$ & Coenagrionidae & Common \\
\hline 21 & $\begin{array}{l}\text { Pixie } \\
\text { Dartlet }\end{array}$ & $\begin{array}{l}\text { Rhodischnara } \\
\text { nursei }\end{array}$ & Coenagrionidae & Rare \\
\hline 22 & $\begin{array}{l}\text { Yellow } \\
\text { Blue Dart }\end{array}$ & $\begin{array}{l}\text { Copera } \\
\text { marginipes }\end{array}$ & Platyenemididae & Common \\
\hline 23 & $\begin{array}{l}\text { Sapphire } \\
\text { Eyed } \\
\text { Spread } \\
\text { Wing }\end{array}$ & $\begin{array}{l}\text { Lestes } \\
\text { praemorsus }\end{array}$ & Lestidae & $\begin{array}{l}\text { Very } \\
\text { rare }\end{array}$ \\
\hline
\end{tabular}

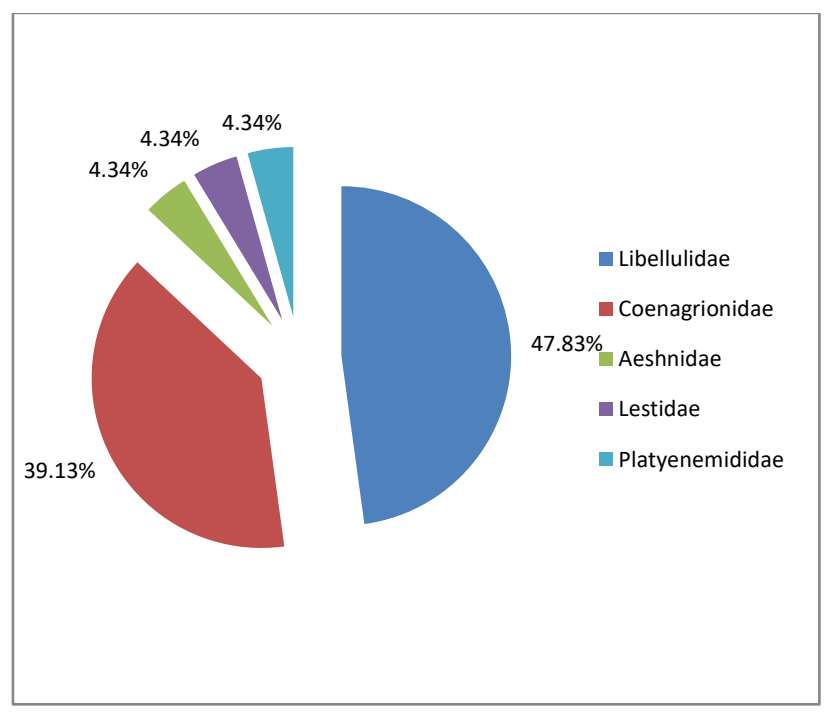

Figure 1: Family wise distribution of odonates in the

\section{REFERENCES:-}

Andrew, R.J., Subramanian K.A. and Tiple A.D. (2009): A Handbook on Common Odonates of Central India. South Asian Council of Odonatology, 65pp.

Fraser, F. C (1920): Indian Dragonflies, VI. Journal of Bombay Natural History Society. 26: 919-932.

Fraser, F. C (1921): Indian Dragonflies, IX. Journal of Bombay Natural History Society. 27:492-498.

Fraser, F.C (1933): Fauna of British India Odonata 1. Taylor and Francis Ltd. London, 423pp.

Fraser, F.C (1934): Fauna of British India Odonata 2. Taylor and Francis Ltd. London,

398pp.

Fraser, F.C (1936): Fauna of British India Odonata 3. Taylor and Francis Ltd. London,

$461 \mathrm{pp}$.

Kulkami, P. P., Babu R., Talmale S., Sinha C. And Mondal S. B. (2012): Insecta: Odonata. In: Fauna of Maharashtra: State Fauna Series. Zoological Survey of India, Kolkata, India, 20(2): 397-428. Maharashtra, India. Journal of Threatened Taxa. 5(7): 4084-4095.

Laidlaw, F. F (1917a): A list of the dragonflies recorded from the Indian empire with special reference to the collection of the Indian museum. Part-II. The family Agrioninae. Records of the Indian Museum. 8:321-348.

Laidlaw, F. F (1917b): A list of the dragonflies recorded from the Indian empire with special reference to the collection of the Indian museum. Part-I.The family Calopterygidae. Records of the Indian Museum. 8:24-40.

Laidlaw, F. F (1919): A list of the dragonflies recorded from the Indian Empire with special reference to the collection of the Indian Museum, Part-II. Rec. Indian Mus., 16: 169-195.

Laidlaw, F. F (1920): Contributions to the study of the dragonfly fauna of Borneo. Part IV. A list of species known to occur in the island.Proceedings of the Zoological Society of London 1920: 311-342. Records Indian Museum. 8: 335349, incl. pl. 16-16.

study area 
Maiolini B. and Carolli M. (2009): Odonata in Trentino (NE Italy): historical and recent data. Studi Trent. Sci. Nat., 84: 11-18.

Mitra, T. R (2006): Handbook of Common Indian Dragonflies (Insecta: Odonata). Zoological Survey of India, 124pp.

Prasad, M. (1996a): Studies on the Odonata fauna of Bastar, Madhya Pradesh, India. Records of Zoological Survey of India. 95:165-213.
Prasad, M. and Varshney R. K. (1996b): An account of Odonata of Maharashtra State, India. Records of Zoological Survey of India. Occ. Paper. No. 95(34):305-327.

Rathod, P. P., Manwar N. A., Pawar S. S., Raja I. A. (2012): Diversity and Abundance of Dragonflies and Damselflies (Order - Odonata) in Agro Ecosystems Around the Amravati City (M.S.), India in Monsoon Season, International Journal of Advanced and Innovative Research.; 1(7):174182. 